\title{
Physician-Assisted Dying: Acceptance by Physicians Only for Patients Close to Death
}

\author{
Julia Zenz $\cdot$ Michael Tryba $\cdot$ Michael Zenz
}

To view enhanced content go to www.paintherapy-open.com

Received: October 20, 2014 / Published online: December 12, 2014

(C) The Author(s) 2014. This article is published with open access at Springerlink.com

\section{ABSTRACT}

This study reports on German physicians' views on legalization of euthanasia and physicianassisted suicide, comparing this with a similar survey of UK doctors. A questionnaire was handed out to attendants of a palliative care and a pain symposium. Complete answers were obtained from 137 physicians. Similar to the UK study, about $30 \%$ of the physicians surveyed support euthanasia in case of terminal illness and more support physician-assisted suicide. In contrast, in both countries, a great majority of physicians oppose medical involvement in

Electronic supplementary material The online version of this article (doi:10.1007/s40122-014-0029-z) contains supplementary material, which is available to authorized users.

J. Zenz (ه)

Ruhr-University Bochum, Kemnaderstr. 342,

44797 Bochum, Germany

e-mail: juliazenz@mail.de

\section{Tryba}

Clinic for Anaesthesiology, Intensive Care and Pain Medicine, Moenchebergstraße 41-43,

34125 Kassel, Germany

\section{Zenz}

Ruhr-University Bochum, Henkenbergstr. 63, 44797 Bochum, Germany

e-mail: zenz@anaesthesia.de hastening death in non-terminal illnesses. The public and parliamentary discussion should face this opposition to assisted suicide by pain and palliative specialists.

Keywords: Euthanasia; Pain; Palliative care; Physician-assisted suicide; Right to die; Terminal care

\section{INTRODUCTION}

There is a tremendous discussion on euthanasia and physician-assisted suicide (PAS) worldwide (e.g., [1]; for definitions see Table 1 [2]). The debate centers on questions of dignity, selfdetermination, or pain [3]. Some European countries, like the Netherlands, Belgium, Luxemburg, and Switzerland, have a liberal legislation. Unlike these countries, Germany has not yet passed any legislation regarding details of end-of-life (EOL) practices. It remains unclear to which group of patients the EOL practices under discussion should be accessible. Is a restriction to terminally ill patients sensible or would any limitation be in conflict with the patients' autonomy? Physicians caring for patients at the end of their life or with an 
Table 1 Definitions of euthanasia and physician-assisted suicide (adapted from Materstvedt et al. [2])

\begin{tabular}{ll}
\hline Euthanasia & $\begin{array}{c}\text { A doctor intentionally killing a person } \\
\text { by the administration of drugs, at } \\
\text { that person's voluntary and } \\
\text { competent request }\end{array}$ \\
$\begin{array}{l}\text { Physician-assisted } \\
\text { suicide }\end{array}$ & $\begin{array}{l}\text { A doctor intentionally helping a } \\
\text { person to commit suicide by } \\
\text { providing drugs for self- } \\
\text { administration, at that person's } \\
\text { voluntary and competent request }\end{array}$ \\
\hline
\end{tabular}

incurable illness are a central group that may be faced with these questions. In the light of the actual discussion and the commencement of the legislative process, a survey among German physicians engaged in the field of palliative care and pain medicine was performed. The recruitment of the respondents took place at a pain symposium and a palliative care congress. The survey aimed to discover the attitudes of those physicians targeted as doctors in EOL care toward PAS and euthanasia. Using practical scenarios rather than questions about 'euthanasia' or 'PAS', the survey aimed at finding out more about the details that are crucial for EOL decision making.

\section{METHODS}

An anonymous questionnaire was handed out to the participants of a palliative care congress and a pain symposium in 2012 (Table 2). Attendants were physicians and nurses; however, the presentation here is limited to the physicians. Regarding personal data, the questionnaire asked about gender, age, occupation, religiousness, and whether the person had attended the death of a patient before. The questionnaire consisted of eight questions, of which the first four are presented here. According to a questionnaire by Seale [4], we asked about the support of the legalization of euthanasia or PAS. Question one and two were related to patients with a terminal illness, questions three and four were related to patients with a non-terminal illness. In addition, the illness was described as "painful" to allude to the physical suffering of the patient in question. The terms 'euthanasia' or 'PAS' were not used explicitly (see Table 2 ).

Possible answers were: "definitely should be allowed", "probably should be allowed", "I don't know", "probably should not be allowed", and "definitely should not be allowed". Statistical analysis was performed using SPSS Version 22.0 (IBM Corporation, Armonk, NY, USA). The significance level was set to $P \leq 0.05$. Chisquare and exact Fisher tests were used to analyze bivariate relationships. For the dichotomous feature of a lethal or nonterminal illness, the non-parametric McNemar test was used.

Table 2 Questionnaire: Medical opinion about assisted dying (adapted from Seale 2009 [4], translated from German)

1. A patient has an incurable, painful illness, from which he will die, for example, cancer. Should a physician be allowed by law to end his life, if the patient asks for that?

2. If this patient asks for it, should a physician be allowed to give them lethal medication so that the patient can take his own life?

3. A patient has an incurable, painful illness, from which he will not die. Should a physician be allowed by law to end his life, if the patient asks for that?

4. If this patient asks for it, should a physician be allowed to give them lethal medication so that the patient can take his own life? 


\section{Compliance with Ethics Guidelines}

The study was approved by the ethics committee of the Ruhr University Bochum (Reg. No. 4502-12).

\section{RESULTS}

The results of this study are part of a study among nurses and physicians submitted in part elsewhere (Zenz J, Tryba M, Zenz M. Euthanasia and physician-assisted suicide: Attitudes of physicians and nurses. Submitted). A total of 317 eligible questionnaires were returned from nurses $(n=180)$ and physicians $(n=137)$. The response rate of physicians was $49 \%$. This article focuses on the responses given by physicians (Table 3).

\section{General Support}

The general acceptance (i.e., "definitely should be allowed" and "probably should be allowed") for life-ending treatment in the case of a terminal illness was high: $32.1 \%$ supported the legalization of euthanasia and $47.4 \%$ supported the legalization of PAS. The general support decreased in the case of a non-terminal illness: $15.3 \%$ for euthanasia and $13.9 \%$ for PAS $(P \leq 0.001$; Table 4).

\section{Definite Support}

The definite support (i.e., "definitely should be allowed") was significantly lower than the general support. In the case of a terminal illness, 6.6\% supported euthanasia and 13.1\% supported PAS. Support was even lower in case of a non-terminal illness: $2.2 \%$ for euthanasia and $1.5 \%$ for PAS (Table 4 ).
Table 3 Demographics of the respondents

\begin{tabular}{|c|c|}
\hline Demographic & $n(\%)$ \\
\hline \multicolumn{2}{|l|}{ Age (years) } \\
\hline$\leq 35$ & $7(5.1)$ \\
\hline $36-45$ & $16(11.7)$ \\
\hline $46-55$ & $70(51.1)$ \\
\hline $56-65$ & $35(25.5)$ \\
\hline$>65$ & $7(5.1)$ \\
\hline Not specified & $2(1.5)$ \\
\hline \multicolumn{2}{|l|}{ Gender } \\
\hline Female & $38(27.7)$ \\
\hline Male & $41(29.9)$ \\
\hline Not specified & $58(42.3)$ \\
\hline \multicolumn{2}{|l|}{ Religion } \\
\hline Not religious & $17(12.4)$ \\
\hline Neither religious nor non-religious & $18(13.1)$ \\
\hline Somewhat religious & $70(51.1)$ \\
\hline Very religious & $23(16.8)$ \\
\hline None of the above & $8(5.8)$ \\
\hline Not specified & $1(0.7)$ \\
\hline \multicolumn{2}{|c|}{ Respondent attended the death of a patient before } \\
\hline Yes & $125(91.2)$ \\
\hline No & $10(7.3)$ \\
\hline Not specified & $2(1.5)$ \\
\hline \multicolumn{2}{|l|}{ Special qualification in palliative care } \\
\hline Yes & $83(60.6)$ \\
\hline No & $54(39.4)$ \\
\hline \multicolumn{2}{|l|}{ Special qualification in pain medicine } \\
\hline Yes & $40(29.2)$ \\
\hline No & $97(70.8)$ \\
\hline $\begin{array}{l}\text { Special qualification in both palliative } \\
\text { care and pain medicine }\end{array}$ & $25(18.2)$ \\
\hline $\begin{array}{l}\text { No special qualification in palliative } \\
\text { care or pain medicine }\end{array}$ & $39(28.5)$ \\
\hline
\end{tabular}


Table 4 Attitudes on assisted dying: Responses to questions one to four by the physicians

\begin{tabular}{|c|c|}
\hline Question/answer & $\begin{array}{l}\text { Responses of the } \\
\text { physicians asked, } n(\%)\end{array}$ \\
\hline \multicolumn{2}{|c|}{$\begin{array}{l}\text { 1. A patient has an incurable, painful illness, from which } \\
\text { he will die, for example, cancer. Should a physician be } \\
\text { allowed by law to end his life, if the patient asks for that? }\end{array}$} \\
\hline Definitely not & $84(61.3)$ \\
\hline Probably not & $9(6.6)$ \\
\hline I don't know & $0(0.0)$ \\
\hline Probably & $35(25.5)$ \\
\hline Definitely & $9(6.6)$ \\
\hline Not specified & $0(0.0)$ \\
\hline \multicolumn{2}{|c|}{$\begin{array}{l}\text { 2. If this patient asks for it, should a physician be allowed } \\
\text { to give them lethal medication so that the patient can } \\
\text { take his own life? }\end{array}$} \\
\hline Definitely not & $64(46.7)$ \\
\hline Probably not & $6(4.4)$ \\
\hline I don't know & $1(0.7)$ \\
\hline Probably & $47(34.3)$ \\
\hline Definitely & $18(13.1)$ \\
\hline Not specified & $1(0.7)$ \\
\hline \multicolumn{2}{|c|}{$\begin{array}{l}\text { 3. A patient has an incurable, painful illness, from which } \\
\text { he will not die. Should a physician be allowed by law to } \\
\text { end his life, if the patient asks for that? }\end{array}$} \\
\hline Definitely not & $105(76.6)$ \\
\hline Probably not & $9(6.6)$ \\
\hline I don't know & $2(1.5)$ \\
\hline Probably & $18(13.1)$ \\
\hline Definitely & $3(2.2)$ \\
\hline Not specified & $0(0.0)$ \\
\hline \multicolumn{2}{|c|}{$\begin{array}{l}\text { 4. If this patient asks for it, should a physician be allowed } \\
\text { to give them lethal medication so that the patient can } \\
\text { take his own life? }\end{array}$} \\
\hline
\end{tabular}

Table 4 continued

\begin{tabular}{lc}
\hline Question/answer & $\begin{array}{l}\text { Responses of the } \\
\text { physicians asked, } \boldsymbol{n}(\%)\end{array}$ \\
\hline Definitely not & $108(78.8)$ \\
Probably not & $7(5.1)$ \\
I don't know & $3(2.2)$ \\
Probably & $17(12.4)$ \\
Definitely & $2(1.5)$ \\
Not specified & $0(0.0)$ \\
\hline
\end{tabular}

\section{Differences Among Physicians \\ with a Special Qualification in the Field of Palliative Care or Pain Medicine}

Physicians with a special qualification in palliative care were more reluctant toward euthanasia and PAS in the case of a terminal illness than physicians without this qualification (Table 5). The definite support for euthanasia in case of a terminal illness was 3.6\% in those physicians with a special qualification in palliative care as opposed to $12.8 \%$ among those without a special qualification. For PAS, this was $9.6 \%$ and $20.5 \%$, respectively. With regard to the general support in the case of a terminal illness, the differences between physicians with a special qualification in palliative care and those without this qualification were significant $(P \leq 0.05)$.

Physicians with a special qualification in pain medicine were also more reluctant toward euthanasia and PAS in the case of a terminal illness than those without a qualification $(2.5 \%$ vs. $12.8 \%$ definite support for euthanasia, respectively; $10.0 \%$ vs. $20.5 \%$ 
Table 5 Responses of physicians with or without special qualification in palliative care and pain medicine

\begin{tabular}{llll}
\hline Question/answer & $\begin{array}{l}\text { Special qualification } \\
\text { in palliative care, } n(\%)\end{array}$ & $\begin{array}{l}\text { Special qualification } \\
\text { in pain medicine, } n(\%)\end{array}$ & No special qualification, $n(\%)$ \\
\hline
\end{tabular}

1. A patient has an incurable, painful illness, from which he will die, for example cancer.

Should a physician be allowed by law to end his life, if the patient asks for that?

$\begin{array}{lccc}\text { Definitely not } & 58(69.9) & 25(62.5) & 17(43.6) \\ \text { Probably not } & 5(6.0) & 2(5.0) & 4(10.3) \\ \text { I don't know } & 0(0.0) & 0(0.0) & 0(0.0) \\ \text { Probably } & 17(20.5) & 12(30.0) & 13(33.3) \\ \text { Definitely } & 3(3.6) & 1(2.5) & 5(12.8) \\ \text { Not specified } & 0(0.0) & 0(0.0) & 0(0.0)\end{array}$

2. If this patient asks for it, should a physician be allowed to give them lethal medication so that the patient can take his own life?

$\begin{array}{lccc}\text { Definitely not } & 46(55.4) & 17(42.5) & 14(35.9) \\ \text { Probably not } & 3(3.6) & 2(5.0) & 3(7.7) \\ \text { I don't know } & 0(0.0) & 1(2.5) & 0(0.0) \\ \text { Probably } & 26(31.3) & 15(37.5) & 14(35.9) \\ \text { Definitely } & 8(9.6) & 4(10.0) & 8(20.5) \\ \text { Not specified } & 0(0.0) & 1(2.5) & 0(0.0)\end{array}$

3. A patient has an incurable, painful illness, from which he will not die.

Should a physician be allowed by law to end his life, if the patient asks for that?

$\begin{array}{llll}\text { Definitely not } & 66(79.5) & 30(75.0) & 29(74.4) \\ \text { Probably not } & 6(7.2) & 4(10.0) & 2(5.1) \\ \text { I don't know } & 1(1.2) & 1(2.5) & 0(0.0) \\ \text { Probably } & 9(10.8) & 5(12.5) & 6(15.4) \\ \text { Definitely } & 1(1.2) & 0(0.0) & 2(5.1) \\ \text { Not specified } & 0(0.0) & 0(0.0) & 0(0.0)\end{array}$

4. If this patient asks for it, should a physician be allowed to give them lethal medication so that the patient can take his own life?

\begin{tabular}{lccc} 
Definitely not & $65(78.3)$ & $32(80.0)$ & $33(84.6)$ \\
Probably not & $5(6.0)$ & $1(2.5)$ & $1(2.6)$ \\
I don't know & $1(1.2)$ & $3(7.5)$ & $0(0.0)$ \\
Probably & $12(14.5)$ & $4(10.0)$ & $3(7.7)$ \\
Definitely & $0(0.0)$ & $0(0.0)$ & $2(5.1)$ \\
Not specified & $0(0.0)$ & $0(0.0)$ & $0(0.0)$ \\
\hline
\end{tabular}


definite support for PAS, respectively). The same holds true regarding patients with a nonterminal illness.

\section{DISCUSSION}

Our study demonstrates that the general support for euthanasia and PAS is rather high in Germany, even among physicians engaged in palliative care and pain medicine. This is in line with figures from the UK where similar questions were asked to general practitioners [4]. There were virtually no differences between the UK data from 2009 and the German data 5 years later. The definite acceptance of euthanasia in terminal illness was $6.6 \%$ in our study and $8.6 \%$ in the UK, and in non-terminal illness acceptance was $2.2 \%$ and $3.5 \%$, respectively [4]. Compared to the on-going legislative discussion on PAS, both surveys were obtained at the same stage. In England and Wales, the legislation was clarified in the Debbie-Purdy case in 2009. In 2010, the End of Life Assistance Bill was rejected by Scottish Parliament. In Germany, the legislative process started this year (2014) and induced a broad general discussion. Nevertheless, the group of respondents of the two studies differs in that the UK study included general practitioners, while our study focused on the participants of conferences on pain or palliative care. Compared to a study performed among palliative care specialists in Germany ten years ago [5], the support has increased. Previously, only $10 \%$ of the physicians asked supported the legalization of euthanasia [5].

It is noteworthy that the definite support was also quite low within our study. The considerable differences in general and definite support show the importance of the phrasing of questionnaires, which can affect the results [6]. We selected concrete questions as opposed to explicitly asking about 'euthanasia'-from the Greek for 'good death', and in German 'Sterbehilfe', that is, 'help to die'. These phrases are often misunderstood and may give false-positive figures [2]. This has to be kept in mind when evaluating polling results during the legislation process. On the other hand, the perception of the word 'euthanasia' can be influenced by history and tradition [7]. This may affect answers, especially in Germany [8]. About $70 \%$ of the German population support euthanasia, but $57 \%$ do not know the legislation on euthanasia [9].

Not surprisingly, a lower support rate for euthanasia and PAS can be detected among palliative care specialists [4, 10-13]. However, some studies concerning Belgian physicians found no influence of training in palliative care on attitudes toward euthanasia and PAS [14, 15]. In Belgium, a "synergistic relationship between palliative care and euthanasia" is seen by some colleagues [16]. Euthanasia is thus seen as a possible option within a palliative care setting complementing, for example, symptom control and psychological support. This holds true in Germany only for a minority of the members of the German Society for Palliative Care [17]. General practitioners both in Germany and the UK feel unprepared for the care of patients at the end of their life [18]. A study among newly qualified physicians showed alack of exposure to patients with a terminal illness during education at medical school [19]. Doctors with more contact to EOL patients (e.g., oncologists, geriatrists) focus more on symptom control rather than accepting discussions on ending their patient's life [13].

The question of the target group of patients could be partially answered by our study. The acceptance of life-ending treatments is significantly lower in the case of a patient 
with a non-terminal illness. This shows that the respondents classify euthanasia and PAS as treatments for patients with a terminal illness. This is in line with the legislation of Oregon [20]. One of the safeguards in Oregon, for example, is that the physician is convinced that the patient only has a life expectancy of 6 months or less. This is in contrast to the Netherlands, where one of the criteria is unbearable suffering with no prospect of improvement without life expectancy limits [21]. However, the law does not define what "unbearable" suffering is. This leaves room for interpretation. In a seminal decision in 1984 (Schoonheim case), the Dutch Supreme Court declared that "unbearable suffering" includes a "loss of dignity" [22]. Since the concept of dignity is a personal one, it remains unclear what unbearable suffering entails. Another important decision by the Supreme Court (Brongersma case, 2002) stated that psychological suffering is also included in the scope of unbearable suffering [22]. "Dignity" was a main reason for euthanasia requests in more than half of the patients [23]. Over the last decades, pain has decreased as main reason for euthanasia requests, whereas deterioration has increased and represents the main reason for requests for euthanasia and PAS in Dutch general practice [24]. Depression is highly associated with the wish to die and the request for euthanasia [25]. In Oregon, in 2013, the top three reasons for people making use of the Death with Dignity Act were: loosing autonomy (93\%), being less able to engage in activities making life enjoyable (88.7\%), and loosing dignity $(73.2 \%)$ [26]. This is in line with data from the Netherlands, where pain no longer is the main reason for euthanasia requests [24]. However, it is noteworthy that more than 50\% of all EOL decisions are made without discussion with patient or family [27].
Dignity, as one of the key aspects of the discussion about EOL decision making, is a vague criterion. Advance directives can be a way to ensure that the patients' wishes are respected in situations when the patient himself cannot communicate. However, in a study among general practitioners from Northern Ireland, only $50 \%$ of the respondents found these directives to be of use in clarifying the situation regarding euthanasia [28]. The questionnaire mentioned did not ask about reasons why the physicians did not find the advance directives useful. Therefore, it remains unclear whether the reluctance refers to advance directives in general or whether this hints to possible difficulties in understanding and implementing the patients' will because of vague or outdated advance directives. Another important aspect is a possible change in the patient's attitudes in the course of illness $[28,29]$. Dignity is not a fixed concept but can develop and change over time. The increase of autonomy of the patient with all its consequences regarding EOL care may also increase the medical power of the health care professionals [29]. This is underlined by studies demonstrating that life-ending drugs are also administered to patients without their explicit request $[27,30]$. Euthanasia and PAS should not be a consequence of poor EOL care [31]. For patients in pain and other physical symptoms improved palliative care provision could reduce euthanasia requests [32].

\section{Limitations}

The number of physicians in our survey is quite limited. However, in the view of the present discussion in Germany, we found attendants of palliative or pain symposia to be a relevant reference group and a survey an urgent need. 
To avoid bias the questionnaire was anonymous, asking only about gender, age, occupation, and religiousness. This should ensure honest answers [33]. However, EOL decision making is a controversial topic and because of the crucial role of the physicians there might still be a certain bias to give socially desirable answers.

The questionnaire used was a German translation of an established questionnaire by Seale [4]. Accordingly, our case vignettes referred to a painful terminal or non-terminal illness to focus on a physical symptom as opposed to a vague and ambiguous concept like loss of dignity [34]. Other questionnaires have also used pain as a leading criterion for a wish to die [35]. Another aspect is that no definition or common aspect of dignity in EOL care exists [34]. Nevertheless, loss of control has proven to be essential within the decisionmaking process of the patient [26].

Another limitation of the study is that the questions do not allow us to draw any conclusions as to whether the respondents are also willing to act according to their answers. The results obtained do not reflect the general opinion of all doctors but provide an insight on the point of view of physicians engaged in palliative care and pain relief.

\section{CONCLUSION}

Our study demonstrates-similar to the data of Seale [4] - that physicians are prepared to accept a wish to die in patients with a terminal illness but are reluctant in accepting to provide assistance in the case of a non-terminal illness. As well, physicians engaged in palliative care and pain therapy may have an acceptance of life-ending treatment in case of terminal illness. This points to the fact that severe deficits still exist for patients at the EOL. Hospice and palliative care must be integrative parts of any discussion on euthanasia and assisted suicide, but possibly do not pose an alternative in all cases. However, the patient's right to die may also include a right to refuse certain "treatments" from the doctor and to discuss alternatives.

\section{ACKNOWLEDGMENTS}

No funding or sponsorship was received for this study or publication of this article. All named authors meet the ICMJE criteria for authorship for this manuscript, take responsibility for the integrity of the work as a whole, and have given final approval for the version to be published.

Conflict of interest. Julia Zenz, Michael Tryba, and Michael Zenz declare no conflict of interest.

Compliance with ethics guidelines. The study was approved by the ethics committee of the Ruhr University Bochum (Reg. No. 4502-12).

Open Access. This article is distributed under the terms of the Creative Commons Attribution Noncommercial License which permits any noncommercial use, distribution, and reproduction in any medium, provided the original author(s) and the source are credited.

\section{REFERENCES}

1. Van der Heide A. Assisted suicide and euthanasia. In: Aminoff $\mathrm{M}$, Boller $\mathrm{F}$, Swaab D, editors. Handbook of Clinical Neurology, 118. Amsterdam: Elsevier B.V.; 2013. pp. 181-189.

2. Materstvedt L, Clark D, Ellershaw J, et al. Euthanasia and physician-assisted suicide: a view 
from an EAPC Ethics Task Force. Palliat Med. 2003;17:97-101.

3. van Alphen J, Donker G, Marquet R. Requests for euthanasia in general practice before and after implementation of the Dutch Euthanasia Act. Br J Gen Pract. 2010;60:263-7.

4. Seale C. Legalisation of euthanasia or physicianassisted suicide: survey of doctors' attitudes. Palliat Med. 2009;23:205-12.

5. Müller-Busch HC, Klaschik E, Woskanjan S. Palliativmedizin: Eine Alternative zur aktiven Euthanasie Dtsch Arztebl International. 2004;101:A-1077. http://www.aerzteblatt.de/int/ article.asp?id=41472. Accessed 10 Nov 2014.

6. Hagelin J, Nilstun T, Hau J, Carlsson H-E. Surveys on attitudes towards legalisation of euthanasia: importance of question phrasing. J Med Ethics. 2004;30:521-3.

7. Cohen J, Marcoux I, Bilsen J, Deboosere P, van der Wal G, Deliens L. European public acceptance of euthanasia: socio-demographic and cultural factors associated with the acceptance of euthanasia in 33 European countries. SocSci Med. 2006;63:743-56.

8. Ernst E. 50 years ago: the Nuremberg Doctors' Tribunal. Part 4: Nazi medicine's relevance today. Wien Med Wochenschr. 1997;147:70-1.

9. Forsa-survey. 2014. http://www.dak.de/dak/ download/Forsa-Umfrage_zur_Sterbehilfe-1358250. pdf?. Accessed 10 Nov 2014.

10. Emanuel EJ, Fairclough D, Clarridge B, et al. Attitudes and practices of US oncologists regarding euthanasia and physician-assisted suicide. Ann Intern Med. 2000;133:527-32.

11. Lee W, Price A, Rayner L, Hotopf M. Survey of doctors' opinions of the legalisation of physician assisted suicide. BMC Med Ethics. 2009;10:2.

12. Marini MC, Neuenschwander H, Stiefel F. Attitudes toward euthanasia and physician assisted suicide: a survey among medical students, oncology clinicians, and palliative care specialists. Palliat Support Care. 2006;4:251-5.

13. Parker M, Cartwright C, Williams G. Impact of specialty on attitudes of Australian medical practitioners to end-of-life decisions. MJA. 2008;188:450-6.

14. Smets T, Cohen J, Bilsen J, Van Wesemael Y, Rurup M, Deliens L. Attitudes and experiences of Belgian physicians regarding euthanasia practice and the euthanasia law. J Pain Symptom Manag. 2011;41:580-93.
15. Van Wesemael Y, Cohen J, Bilsen J, Smets T, Onwuteaka-Philipsen B, Deliens L. Process and outcomes of euthanasia requests under the Belgian act on euthanasia: a nationwide survey. J Pain Symptom Manag. 2011;42: 721-33.

16. Bernheim J, Distelmans W, Mullie A, Ashby M. Questions and answers on the Belgian model of integral end-of-life care: experiment? Prototype?: "EU-euthanasia": the close historical, and evidently synergistic, relationship between palliative care and euthanasia in Belgium: an interview with a doctor involved in the early development of both and two of his successors. J Bioeth Inq. 2014. (Epub ahead of print).

17. Schildmann J, Hoetzel J, Mueller-Busch C, Vollmann J. End-of-life practices in palliative care: a cross sectional survey of physician members of the German Society for Palliative Medicine. Palliat Med. 2010;24:820-7.

18. Maitra R, Harfst A, Bjerre L, Kochen M, Becker A. Do German General practitioners support euthanasia? Eur J Gen Pract. 2005;11:94-100.

19. Gibbins J, McCoubrie R, Forbes K. Why are newly qualified doctors unprepared to care for patients at the end of life? Med Educ. 2011;45:389-99.

20. Oregon Death with Dignity Act. http://public.health. oregon.gov/ProviderPartnerResources/Evaluation Research/DeathwithDignityAct/Pages/ors.aspx. 10 Nov 2014

21. Termination of Life on Request and Assisted Suicide (review procedures) Act Upper House of the States General Parliamentary year 2000-2001 No. 137.

22. van Tol D, Rietjens J, van der Heide A. Judgment of unbearable suffering and willingness to grant a euthanasia request by Dutch general practitioners. Health Policy. 2010;97:166-72.

23. Gordijn B. Die derzeitige Euthanasie-Debatte in den Niederlanden. In: Aulbert E, Klaschik E, Pichlmaier $\mathrm{H}$, editors. Palliativmedizin-Die Alternative zur aktiven Sterbehilfe. Stuttgart New York: Schattauer; 1998. pp. 9-22.

24. Marquet RL, Bartelds A, Visser GJ, Spreeuwenberg P, Peters L. Twenty five years of requests for euthanasia and physician assisted suicide in Dutch general practice: trend analysis. BMJ. 2003; 327:201-2.

25. van der Lee $M$, van der Bom J, Swarte N, Heintz A, de Graeff A, van den Bout J. Euthanasia and depression: a prospective cohort study among terminally ill cancer patients. J Clin Oncol. 2005;23:6607-12. 
26. Death with Dignity Act Oregon 2013. https:// public.health.oregon.gov/ProviderPartnerResources/ EvaluationResearch/DeathwithDignityAct/Docum ents/year16.pdf. Accessed 10 Nov 2014.

27. van der Heide A, Deliens L, Faisst K, et al. End-of-life decision-making in six European countries: descriptive study. Lancet. 2003;362:345-50.

28. McGlade K, Slaney L, Bunting B, Gallagher A. Voluntary euthanasia in Northern Ireland: general practitioners' beliefs, experiences, and actions. Br J Gen Pract. 2000;50:794-7.

29. Karlsson M, Milberg A, Strang P. Dying cancer patients' own opinions on euthanasia: an expression of autonomy? A qualitative study. Palliat Med. 2012;26:34-42.

30. Chambaere K, Bilsen J, Cohen J, OnwuteakaPhilipsen B, Mortier F, Deliens L. Physicianassisted deaths under the euthanasia law in Belgium: a population-based survey. CMAJ. 2010;182:895-901.
31. Back A, Pearlman R. Desire for physician-assisted suicide: requests for a better death? Lancet. 2001;358:344-5.

32. Steinhauser K, Christakis N, Clipp E, McNeilly M, McIntyre L, Tulsky J. Factors considered important at the end of life by patients, family, physicians, and other care providers. JAMA. 2000;284:2476-82.

33. Merry AF, Moharib M, Devcich DA, et al. Doctors' willingness to give honest answers about end-of-life practices: a cross-sectional study. BMJ Open. 2013;3:1-8.

34. Guo G, Jacelon C. An integrative review of dignity in end-of-life care. Palliat Med. 2014;28:931-40.

35. Schröder C, Schmutzer G, Klaiberg A, Brähler E. Ärztliche Sterbehilfe im Spannungsfeld zwischen Zustimmung zur Freigabe und persönlicher Inanspruchnahme-Ergebnisse repräsentativen Befragung Bevölkerung. Psychother 2003;53:334-43. der deutschen Psych Med. 